\title{
Structure and utilisation possibilities of channel digital model in example of Vistula river in Warsaw
}

\author{
MICHAŁ BRACH ${ }^{1}$, TOMASZ FALKOWSKI ${ }^{2}$, PIOTR OSTROWSKI ${ }^{2}$, \\ MAREK PRZYWÓZKI ${ }^{1}$ \\ ${ }^{1}$ Department of Forest Management Planning, Geomatics and Forest Economics \\ ${ }^{2}$ Department of Geotechnical Engineering \\ Warsaw University of Life Sciences - SGGW
}

\begin{abstract}
Structure and utilisation possibilities of channel digital model in example of Vistula river in Warsaw. During the analysis of channel processes, high dynamicity of fluvial environments in the area of Polish Lowland imposes the necessity to use spatial channel models, always defined for specific flow conditions. In this paper, a procedure to construct a digital model of the Vistula channel zone morphology in a GIS environment has been proposed, based on: results of the bathymetric examinations conducted by means of an assembly consisting of an echosounder coupled with a DGPS receiver; GNSS RTK measurements; analysis of remote sensing materials and digital terrain model. Examples regarding the use of so created models to characterise the environment of the Warsaw Vistula channel have been presented. The Vistula channel within the examined segment is a form with diverse morphodynamics. It consists of a quasi-natural zone, characterised by a relative ease of erosion and deposition processes, and an engineered channel zone. Apart from the hydrotechnical structures, a factor which conditions the character of contemporary channel processes along the engineered segment is its geological structure, mainly morphology and lithology of the contemporary Vistula alluvia substratum.
\end{abstract}

Key words: channel zone digital model, GIS, channel morphodynamics, GNSS-RTK

\section{INTRODUCTION}

Difficulties that accompany the examinations of the fluvial environment of lowland rivers result not only from its frequent physical inaccessibility. Its source is also the necessity to analyse a large amount of diverse information, which is a record of both the current status of the river channel, as well as the course of its evolution. The identification of the environmental status of river channel therefore requires precise determination of the spatial and temporal relations between all the elements conditioning the functioning of such a complex system. The GIS environment is an ideal tool to conduct such analyses (Zwoliński et al. 2010).

For the last several years a significant development of GIS software has been observed regarding the creation of advanced spatial models. The data of the spatial nature constitutes a key element when building a digital world on the computer screen, not just in two, but also in three dimensions. An example of the use of GIS technology in the examinations of lowland river valleys may be the analysis of channel zone morphodynamics. Its results are utilised for example in hydraulic engineering or flood control (Chen et al. 2004). 
A digital model of floodplain morphology in a portion adjacent to the channel may be built based on field geodesic measurements, terrestrial - TLS, or airborne laser scanning - ALS (Kociuba et al. 2013). Nowadays the source data utilised to build a channel bottom model is gathered during the bathymetric measurements complemented by geodesic measurements. An effective way of conducting the echo sounding examinations is the utilisation of assemblies consisting of an echosounder integrated with a GPS receiver (Ostrowski 2006). They allow for relatively fast measurements of vast channel fragments under almost any hydrological conditions (e.g. during passage of the flood wave). The bathymetric (depth) maps are a direct result of such examinations. Their usefulness for the analyses of a fluvial environment is however limited, because they do not take into account a significant channel environment element that is the river longitudinal profile. This fact makes it also impossible to directly include the results of bathymetric examinations in the construction of the digital model of the channel zone morphology (e.g. DTM). The use of GNSS-RTK type devices in the hydrographical assemblies does not bring satisfactory results in this case due to the necessity to stabilise the device during establishing the altitude of the measurement point. Also, eliminating the impact of waves on the location of the instrument, or the cants of the boat would require the use of gyroscopic constructions, whose effectiveness regarding the measured values (average slopes of lowland rivers are lower than 1\%o, Dębski 1970) is problematic. The bathymetric maps constructed based on the interpolation of the data from the measurement points forming a cloud must be therefore transformed into hypsometric maps based on additional measurements of water surface levels. To calculate the altitude of the points representing river channel bottom we need to subtract the depth values recorded by the echo sounder from the water surface elevations.

The construction method regarding a channel zone spatial model of a large lowland river has been presented in the paper. A fragment of the Vistula channel in the Warsaw area was the testing ground (Fig. 1). Within its individual reaches, it is characterised by varying reactions to the changes in flow conditions, resulting from the evolution of the river as a result of natural processes and the anthropogenic impact (Starkel 1982, 2001, see also Vanderberghe 2002).

Since the middle of 20 th century, the constant lowering of the medium and low water levels has been recorded in the Vistula channel in Warsaw (Zielińska 1960). This phenomenon is associated with channel engineering (its narrowing), as well as the river bedload exploitation (Żelaziński et al. 2005, Gutry-Korycka et al. 2006). At the same time building up of the channel bottom surface and decreasing its hydraulic conveyance ability is observed upstream and downstream the city reach, especially nowadays (Falkowski and Ostrowski 2012). This phenomenon causes a periodic increase in the risk of flood.

\section{AIM OF STUDY, MATERIAL AND METHODS}

The aim of the conducted work was to create a construction procedure for the digital model of the river bottom in analysed zone, by means of which it would 

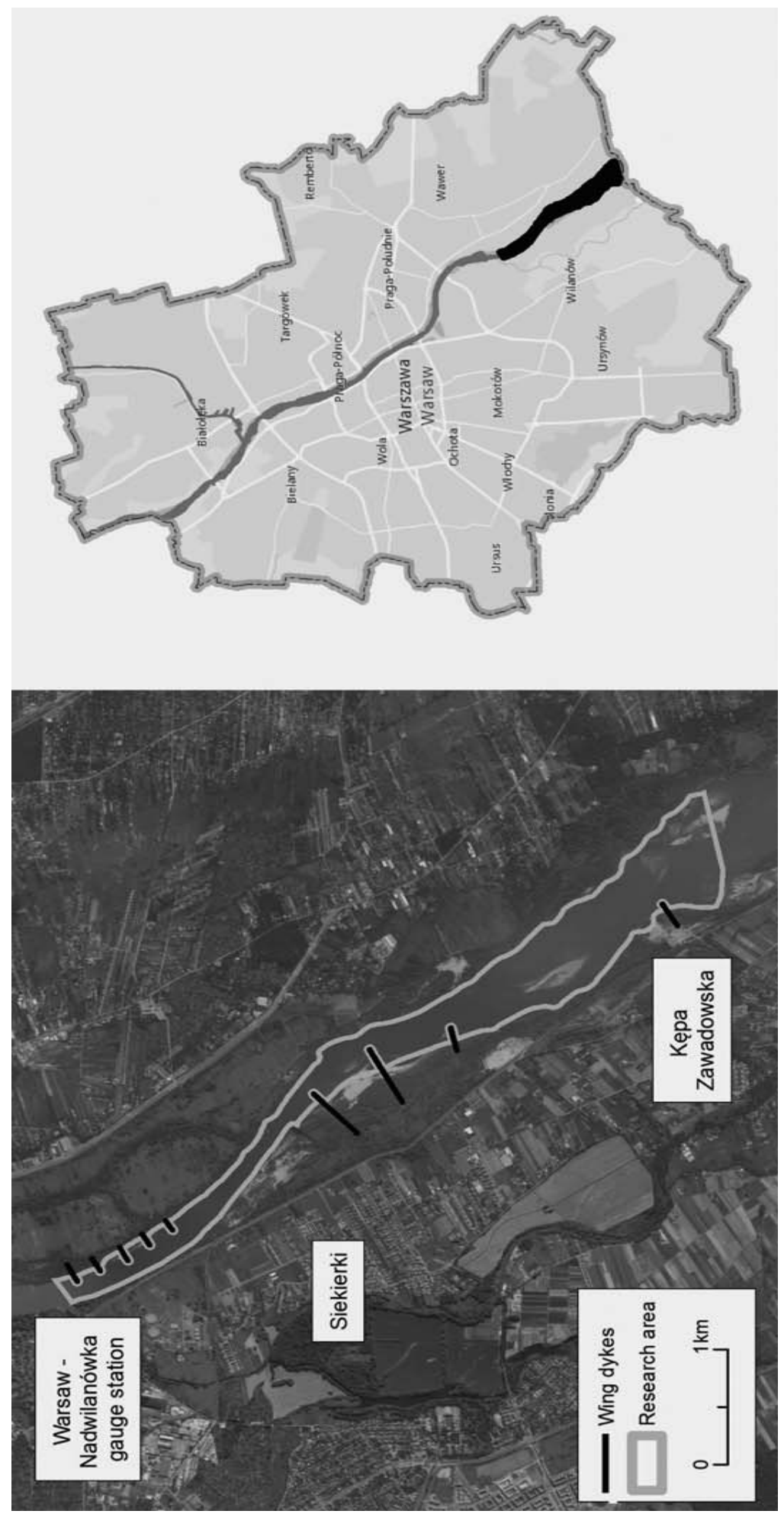

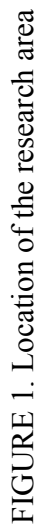


be possible to archive the channel morphology changes, recorded during the bathymetric measurements conducted in June and July 2011 (Fig. 2). The area included in the research constituted an 8-km river reach, beginning at the south-eastern administrative border of Warsaw and extending towards its centre (Fig. 1).

A set of devices was used to perform the measurements, including a SonarLite portable echosounder from the British Ohmex company and, coupled with it, a DGPS FX 324 MAP Color receiver from the Thales Navigation company. The integrated measurement assembly allowed for simultaneous recording of the water depth at a given point of the channel along with the corresponding XY Cartesian coordinates. The dataset was filtered regarding the errors resulting from incorrectly reflected echosounder signal. Preparation of the final river channel model was possible due to proper processing and merging of the spatial data originating from several different sources (Fig. 3). The ArcGIS 10.1 software suite from the Esri company was used for the implementation of the project, enabling to perform geoprocessing in the ArcMap module, along with the 3D Analyst and Spatial Analyst extensions. The final visualisations were prepared in the ArcScene module, allowing for presentation of spatial data in a three-dimensional perspective.

One of the key problem in creating three-dimensional surface is to find the best interpolation method. There were many researches considering spatial interpolation in bathymetry, however, the conclusions show that this techniques still need further research ( $\mathrm{Li}$ and Heap
2008, Tan and Xu 2014). This does not change the fact that the most common and accurate methods of interpolation are inverse distance weighting and ordinary kriging (Malejka et al. 2012, Šiljeg et al. 2015). The first step of the work was an interpolation of the bathymetric data by means of the inverse distance weighting method (IDW). Its purpose was to create a raster map presenting the channel bottom morphology. Interpolation is one of the best methods of obtaining values for an examined phenomenon in areas where no measurements have been taken. The irregular character of the data from the bathymetric measurements is perfectly suitable for utilising this technique. The proposed IDW method gives credible results of surface morphology for this type of objects, which has been confirmed through scientific research (Chaplot et al. 2006, Merwade 2009). The final image did not yet constitute an exact representation of the channel bottom morphology, but just its initial presentation generated based on the vertical distance between the echosounder's processor and the bottom of the river. In order to obtain the correct terrain altitudes of the channel bottom it was necessary to take into account the actual baseline for the conducted measurements, meaning the water surface altitudes. In order to do so, the water surface altitudes were measured using the GNSS RTK technology in the selected fragments of the river reach in question, with a vertical accuracy of $\pm 0.05 \mathrm{~m}$ along with the $\mathrm{XY}$ coordinates with the horizontal accuracy of $\pm 0.03 \mathrm{~m}$ (Bosy et al. 2007). By doing so, 17 reference points distributed approximately every $500 \mathrm{~m}$ were obtained. They helped to create a water surface model by means 


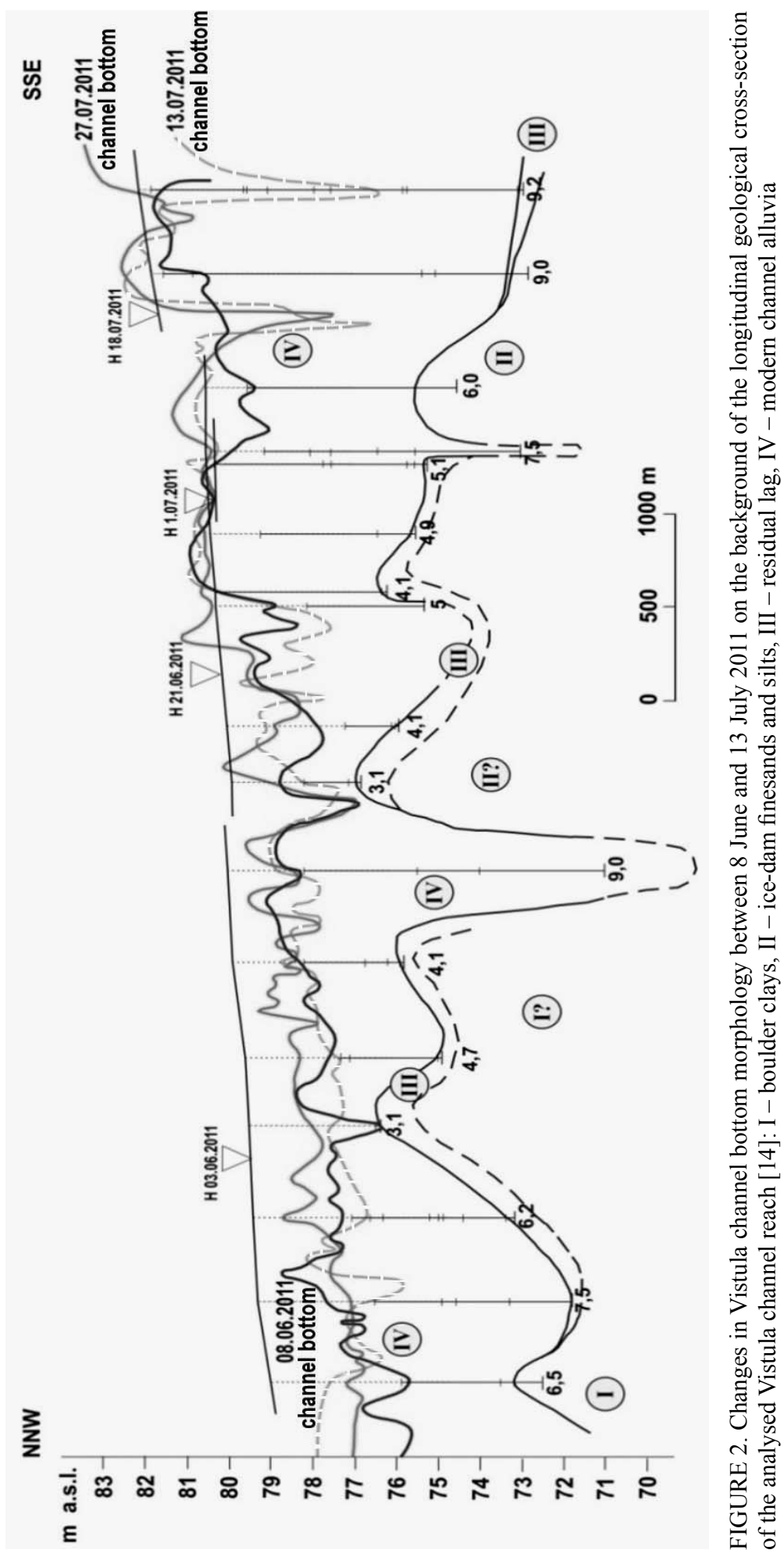




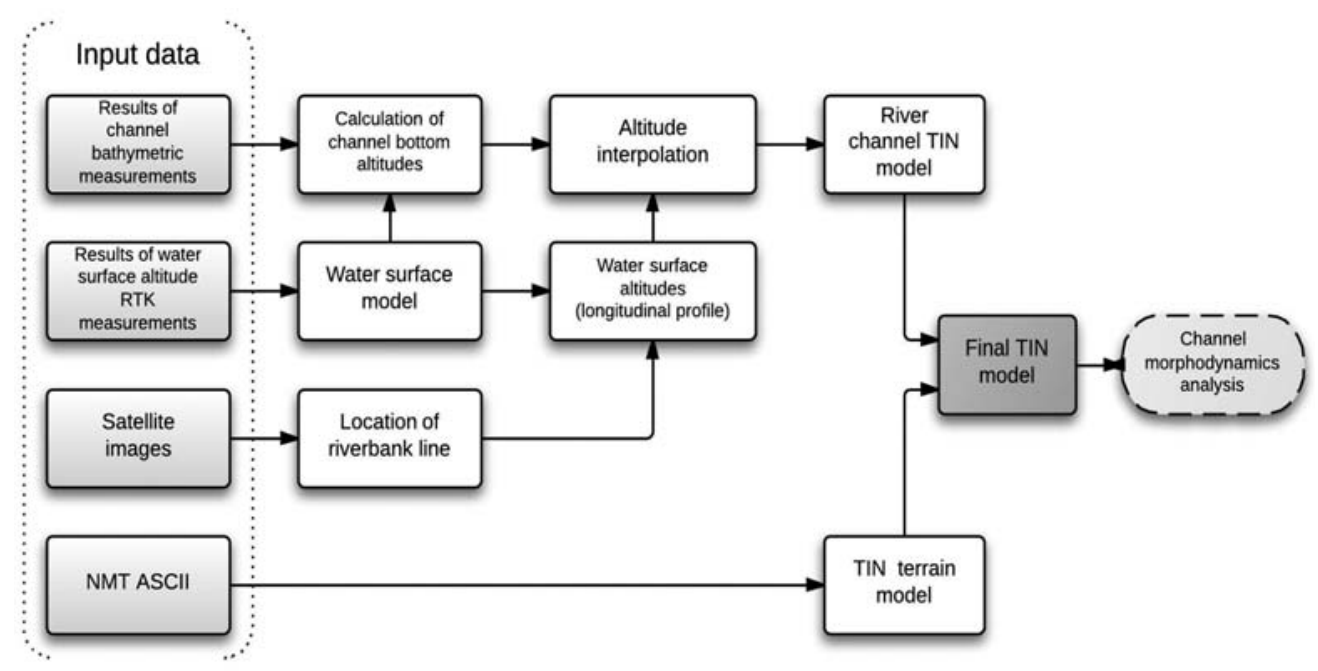

FIGURE 3. Data integration chart

of the kriging method, allowing for additional elimination of errors resulting from the boat with the measurement equipment rocking in the water (Desbarats et al. 2001). Regular distribution of GNSS RTK measurement points allowed for achieving a credible surface (Fig. 4). Due to the utilisation of this technique it was possible to apply the proper and actual inclination of every water surface reach located between the individual measurement points. The use of basic raster subtraction operation allowed for finding the difference between the water surface model and the river channel depth. By doing so, the proper terrain altitudes for the bottom of the Vistula fragment in question were obtained (Fig. 5). Because it is necessary for further data interpolation to have the data presented as point information layers, the river channel model has been transformed from a raster format into a vector format. In order to do so, a regular grid of points with an interval of $10 \mathrm{~m}$ was generated for the area in question. The $\mathrm{X}, \mathrm{Y}$ and $\mathrm{Z}$ coordinates were assigned to these points. The $\mathrm{Z}$ coordinate came from the raster image created by merging the interpolation results for the channel model and water surface (Figs 4, 5).

The terrain altitudes along the riverbank line were the missing element of the dataset in possession. Direct measurements of this area by means of an echosounder are not possible. This is due to the construction of the echosounder's transducer, which requires water depth of above $0.3 \mathrm{~m}$ for successful measurements. The course of the line which divides water and land was determined based on the interpretation of contemporary satellite images and subsidiary GPS measurements performed in the field. By utilising the previously created water surface model, the altitude data along the riverbank line was obtained from it, recorded as points containing the XYZ coordinates. Before commencing the collective interpolation of all the data, it was 


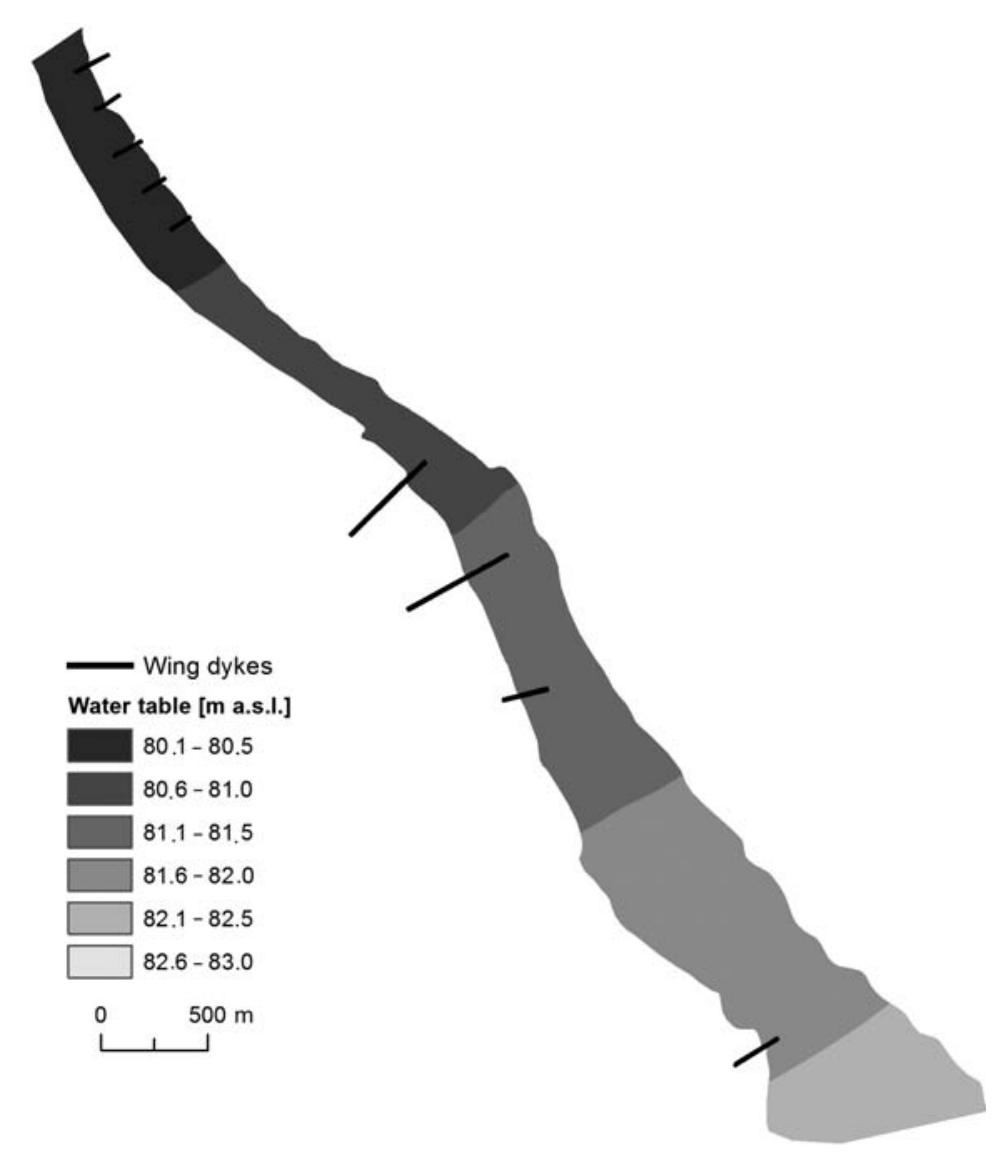

FIGURE 4. Water surface model created based on the GNSS RTK measurements

necessary to integrate them. Sets of point data are an input element for each type of interpolation. In this case such set consisted of riverbank line points along with points obtained from the raster model of the channel bottom. Deletion of some of the points from the channel bottom model was necessary in order to avoid possible errors in the final interpolation. The altitudes located along the edge of the river do not depict the actual shape of the channel. This task was executed by means of a negative selection of points located $10 \mathrm{~m}$ from the previously determined riverbank line. Eventually the layers were merged, obtaining a dataset which was further used to perform the final interpolation by means of the IDW method (Fig. 6).

The interpolation result was achieved in a raster form, which is not an optimal format for three-dimensional visualisation. That is why it has been converted into a TIN (Triangulated Irregular Network) model, one of the popular three-dimensional data storage formats (Gruszczyński 2005, Klein 2006). The resulting model is a simplified representation of the actual status of the bottom of the researched river fragment, depicting 


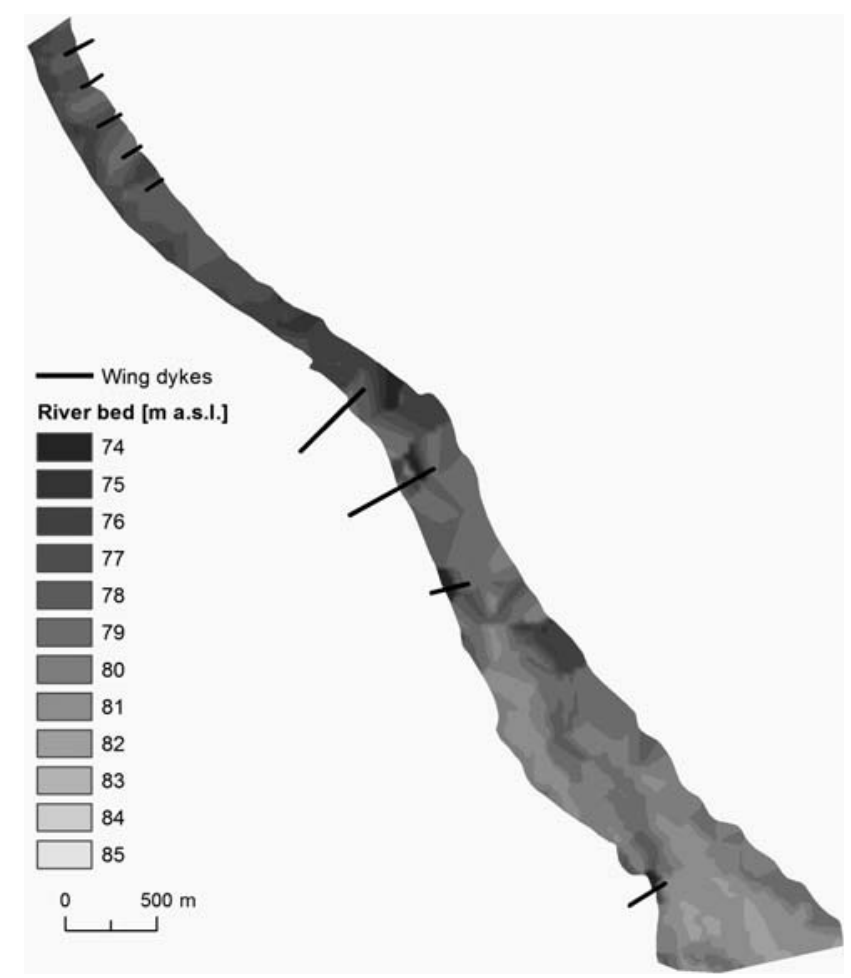

FIGURE 5. River channel model created based on the bathymetric measurements, taking into account the water surface model

the characteristic features of its morphology. However, it depicts the morphology of the river channel bottom only while performing the bathymetric measurements.

In order to prepare a channel zone model of the river it was necessary to combine the data related to the channel bottom with the data related to the floodplain and areas adjacent to it. A good source of this kind on information proved to be the database of the Geodesic and Cartographic Documentation Centre containing the XYZ coordinates of the surface of the areas located on both sides of the channel, created using an ASCII format. A characteristic feature of this dataset is the lack of information about the channel bottom morphology, or the altitudes of the water surface itself, which is associated with the specifics of the laser scanning (ALS - Airborne Laser Scanning) technique, used to create the digital terrain model. The occurring phenomenon of the laser beam being absorbed by water contributes to obtaining an infinitesimal amount of reflected signal, which, when put into practice, eventually translates into the lack of credible altitude data (Antonarakis et al. 2008). The created TIN model of the surface morphology therefore had a places with missing data allowing merge with the bathymetric measurement 


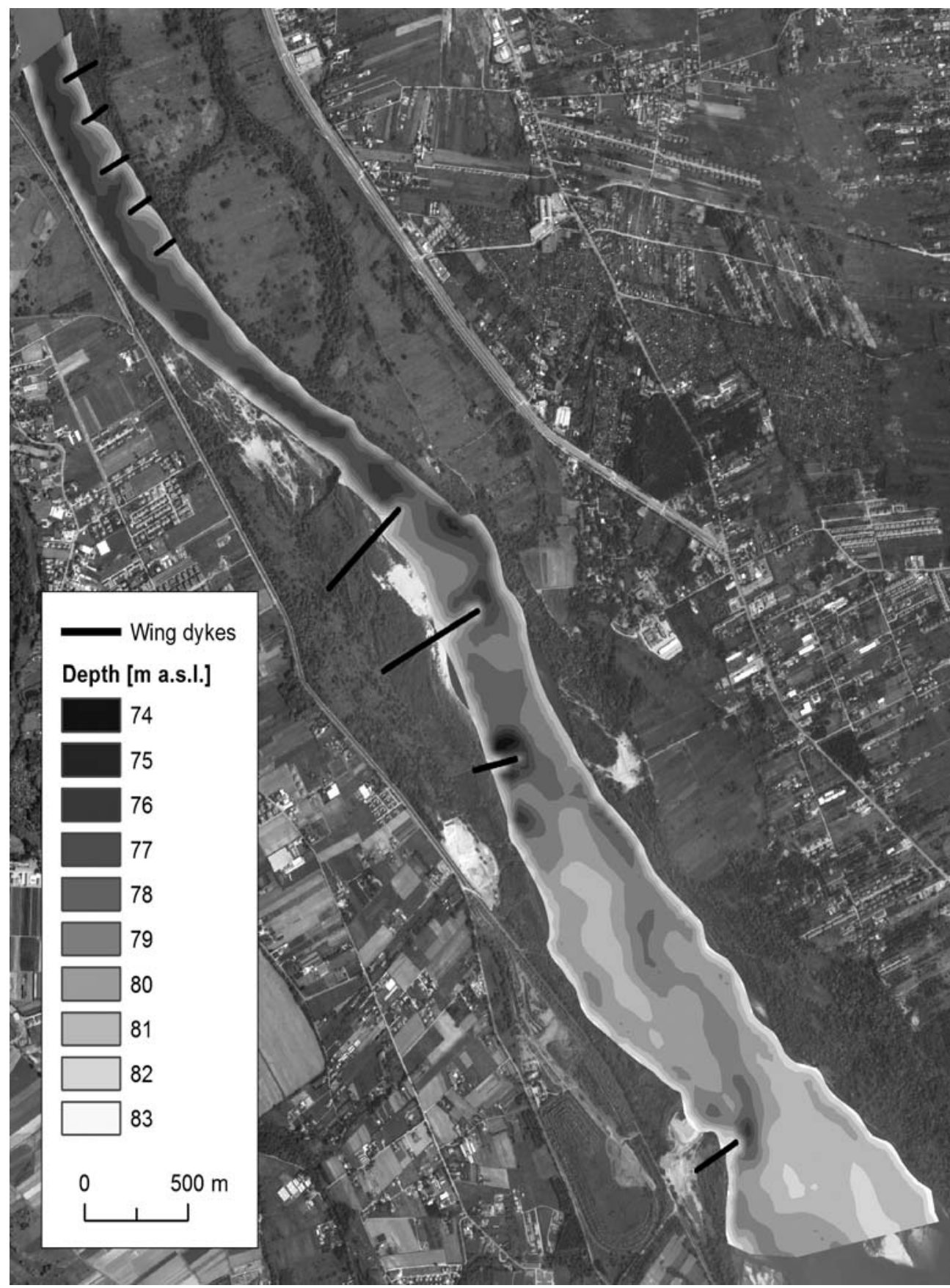

FIGURE 6. Result of the final interpolation of the collective data for the reach of the Vistula river channel bottom 


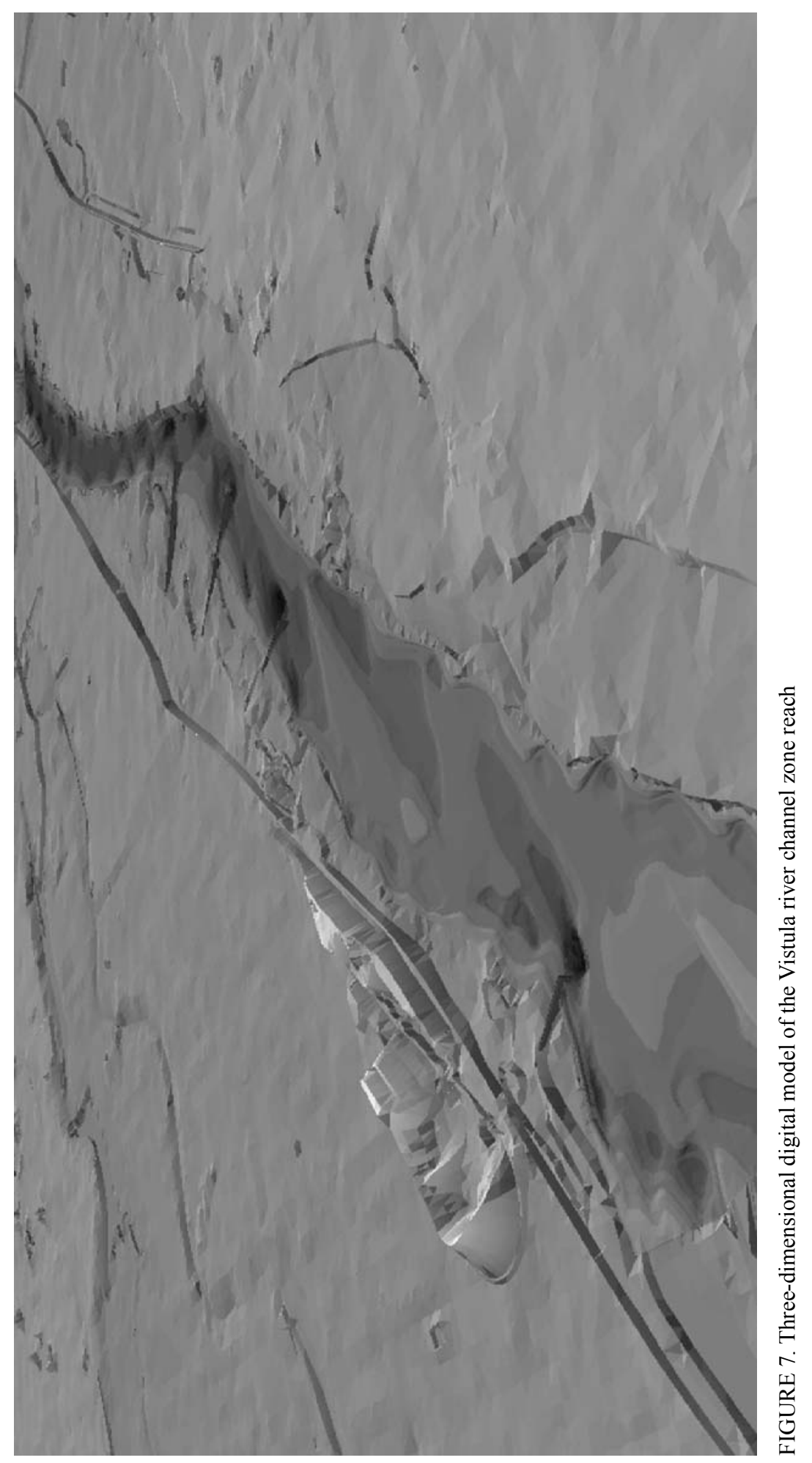


results. Keeping the same 1992 National System of Geodesic Coordinates for both models allowed for obtaining the final TIN model of the river channel zone and its full visualisation (Fig. 7).

\section{RESULTS AND DISCUSSION}

The methodology of creating a river channel zone spatial morphology model shown above presents a high potential for application. As visible from the geological cross-section created along the axis of the channel (Fig. 2), the location of the bottom is characterised by high changeability in time. In the period between May and July 2011 the differences in the bottom altitudes within the analysed portion reached locally as much as $6.5 \mathrm{~m}$. However, the magnitude of changes interpreted from the cross-section line (transverse or longitudinal) does not allow for observing the actual tendencies regarding the course of the channel processes. The proper identification of the character and scale of the channel morphology changes is possible to be performed only based on the comparison of its spatial models, constructed separately for each water level/measurement series.

The analysed Vistula channel reach consists of three fragments with various morphodynamics: the quasi-natural zone of the Kępa Zawadowska region, the engineered reach of the Siekierki region and the intermediate zone which connects them (Falkowski and Ostrowski 2012) - Figure 1. As seen when comparing the spatial models of the channel constructed for low, medium and high water levels, created based on the presented methodology (Falkowski and
Ostrowski 2012), the changes in the location of the bottom within the lower engineered reach (reaching over $4 \mathrm{~m}$ ) shown on the cross-section (Fig. 2) are associated mainly with the adaptations of the thalweg curvature to the magnitude of flow in the channel (Allen 1970). Spatial limitation of the erosion process is related in this reach to the engineering of the banks and the location of the top surface of the contemporary alluvia substratum which is hard to be washed out. Channel morphology changes within the quasi-natural reach (upper fragment of the analysed zone) are of a different nature. The fact of the river being overburdened with alluvia manifests itself, especially when the flood waves have dispersed, by creating new channel meso-forms. Their presence affects the thalweg system, branched within this reach, and causes previously created forms to be washed out. The ease of channel morphology changes is higher within this reach due to its width and relatively great depth at which the top of the alluvia substratum is located. The substratum characterised by high resistance to being washed out is present in here at the average depth of approximately $10 \mathrm{~m}$ below the medium water level.

The assessment of channel morphology changes based on its models constructed under various flow conditions also allows for identification of zones where the stable bottom is present. Its presence may not only indicate the occurrence of local base levels stabilising the longitudinal profile of the channel (Schumm and Thorne 1989). It may also indicate the existence of lasting tendencies to concentrate the current, which may also be related to the geological structure of the 
channel (Falkowski 2007). Considering such elements in channel engineering projects increases the durability and reliability of hydraulic structures (Thorne et al. 1997, Gilvear 1999, Eaton and Millar 2004).

The construction method of a channel digital elevation model presented in this paper may also be useful in the analysis of speed distribution changes in the river channel under various flow conditions (Gutry-Korycka et al. 2006). In the case of rivers with a varying channel, shaped in the alluvial layer, such analyses should be conducted only based on its current spatial model, defined for the given water level. Based on the speed distributions obtained during hydrodynamic modelling under the flow conditions of high water, three zones of flow conditions have been distinguished within the analysed reach. The first zone in the vicinity of Kępa Zawadowska is characterised by an even water velocity distribution. The increase in speed occurs in the second intermediate zone, except for the area between the groynes, where flow turbulences are observed along with the decrease in speed. The third zone located in the vicinity of Siekierki is characterised by a large increase in speed and its diversification in the transverse cross-sections as well as along the width. This zone is characterised by large stream turbulences. The flow speeds in the lower zone, which was engineered under the conditions of medium water levels, are almost twice as high as the flow speeds in the current zone of the quasi-natural reach of the Kępa Zawadowska area. The concentration of flow in the narrowed engineered channel is, along with the geological structure, the main reason behind the shaping of the transitional character of this reach.

As mentioned initially, under the low and medium water flow conditions lowering of the flow level is observed in the Warsaw reach of the Vistula channel, which is associated with the concentration of flows and extraction of the debris (Żelaziński et al. 2005). At the same time both above (in the vicinity of Kępa Zawadowska), as well as below the city reach the increase in the amount of deposed debris is observed, which shapes extensive channel forms in here. The construction method of a channel morphology digital model presented in the paper may also be useful in the analyses regarding the intensity of the debris transport. The estimation of bottom transport intensity (based for example on direct measurement) may be supported by recording the bottom morphology changes in the transverse transects separated from the spatial models of the channel, constructed for constant time intervals.

The described procedure allows for integration and transformation of geospatial data originating from various sources - gathered as a result of field research (raw data from echo sounding, water surface levelling, riverbank line mapping) and archival data - into a digital, three-dimensional channel zone model of a large lowland river. Generation of models by means of the proposed method is relatively simple, which justifies (also economically) creation and comparison of heterochronous models, and consequently the study of the dynamicity course of the processes occurring in the channel zone. Features of the digital models created by means of the proposed method allow for its wide usage in environmen- 
tal analyses, including for example the geological structure of the channel zone, flow dynamicity and debris transport. It should be noted that the proposed method allows for construction of channel zone models for various hydrological conditions, including overbank flows, which is especially significant when designing, assessing the safety or environmental impact of engineering structures (e.g. bridges) located within the channel.

\section{CONCLUSIONS}

- The designed method allows for creating three-dimensional digital elevation models of a large river bottom based on field measurements (bathymetric data, GNSS-RTK measurements) and the DTM archival data available for the floodplain area.

- Data integration occurs within the GIS environment, ensuring (due to assigning georeferential attributes to the models) their full scalability along with the possibility of comparison to future models. The use of GIS environment along with the files being generated in standard formats enables the information to be easily accessible also by users who use non-commercial applications.

- The designed method is characterised by huge universality. Channel zone models for various hydrological conditions may be created by means of it, both within the reaches whose character is similar to natural as well as those subject to significant anthropogenic transformations.

- Three-dimensional channel zone model of a river, and especially the comparison between several heterochronous models allow for relatively easy performance of multiple river channel zone analyses. Among them are: the identification of character and the scale of channel morphology changes, assessment of spatial differentiation of the debris transport intensity, or the assessment of flood risk in the individual valley fragments. Results of such analyses may be highly valuable for the broadly defined river engineering as well as flood control.

\section{REFERENCES}

ALLEN J.R.L. 1970: Physical processes of sedimentation. George Allen and Unwin LTD, London.

ANTONARAKIS A.S., RICHARDS K.S., BRASINGTON J. 2008: Object-based land cover classification using airborne LiDAR. Remote. Sens. Environ. 112 (6): 2988-2998.

BOSY J., GRASZKA W., LEOŃCZYK M. 2007: ASG-EUPOS. A Multifunctional Precise Satellite Positioning System in Poland. Eur. J. of Navi. 5 (4): 2-6.

CHAPLOT V., DARBOUX F., BOURENNANE H., LEGUÉDOIS S., SILVERA N., PHACHOMPHON K. 2006: Accuracy of interpolation techniques for the derivation of digital elevation models in relation to landform types and data density. Geomorphology 77, 126-141.

CHEN Y., ZHU D., ZHAO J. 2004: Small basin flash flood simulation with TOPMODEL. In: GIS and Remote Sensing in Hydrology, Water Resources and Environment. Y. Chen, K. Takara, I. Cluckie, F.H. De Smedt (Eds). IAHS Publ. 289, 41-49.

DĘBSKI K. 1970: Hydrologia [Hydrology]. PWN, Warszawa (in Polish).

DESBARATS A.J., LOGAN C.E., HINTON M.J., SHARPE D.R. 2002: On the kriging of water table elevations using collateral information from digital elevation model. J. of Hydrol. 255, 25-38.

EATON B.C., MILLAR R.G. 2004: Optimal alluvial channel width under bank stability constraint. Geomorphology 62, 35-45. 
FALKOWSKI E. 1971: Historia i prognoza rozwoju układu koryta wybranych odcinków rzek nizinnych Polski [History and prognosis for the development of bed configurations of selected sections of Polish lowland rivers]. Biuletyn Geologiczny 12, 5-122 (Engl. summ.).

FALKOWSKI E. 1982: Some regularities of the valley floor evolution of the Middle Vistula river valley. In: L. Starkel (Ed.). Evolution of the Vistula river valley during the last 15000 years. Geogr. Stud. Special Issue 1, 9-20.

FALKOWSKI E. 1990: Morphogenetic classification of river valleys developing in formerly glaciated areas for needs of mathematical and physical modeling in hydro-technical projects. Geographia Polonica 58: 55-67.

FALKOWSKI T. 2007: Alluvial bottom geology inferred as a factor controlling channel flow along the Middle Vistula River, Poland. Geological Quarterly 51 (1), 91-102.

FALKOWSKI T., OSTROWSKI P. 2009: Budowa geologiczna strefy korytowej Wisły warszawskiej i jej znaczenie dla związanej z korytem infrastruktury [The Vistula River channel zone geology and its importance for the river infrastructure stability]. Nauka Przyroda Technika, Mel. i Inż. Środ. 3, (3), \# 82 (Engl. summ.).

FALKOWSKI T., OSTROWSKI P. 2012: Wpływ budowy geologicznej na zróżnicowanie dynamiki procesów korytowych w warunkach silnej antropopresji na przykładzie Wisły warszawskiej [Geologic structure influence on channel processes of regulated river in example of $\mathrm{Vi}$ stula River reach in Warsaw]. Acta Geographica Lodziensia 100, 51-63 (Engl. summ.).

GILVEAR D.J. 1999: Fluvial geomorphology and river engineering: future roles utilizing a fluvial hydrosystems framework. Gemorphology 31, 229-245.

GRUSZCZYŃSKI S. 2005: The Assessment of Variability of the Concentration of Chromium in Soils with the Application of Neural Networks. Pol. J. Environ. Stud. 14 (6), 743-751.

GUTRY-KORYCKA M., MAGNUSZEWSKI A., SUCHOŻEBERSKI J., JAWORSKI W., MARCINKOWSKI M., SZYDŁOWSKI M. 2006: Numerical estimation of flood zones in the Vistula River Valley. IAHS Publ. 308, 191-195 .

KAŁMYKOW-PIWIŃSKA A., FALKOWSKI T. 2012: Assesment of the channel morphologic stability in the base of archival cartographic and photogrametric data in GIS environment. Przeglad Naukowy Inżynieria i Ksztaltowanie Środowiska 21 (4), 251-262 (Engl. summ.).

KLEIN A. 2006: Identification of submarine banks in the North Sea and the Baltic Sea with the aid of TIN modeling. Progress in Marine Conservation in Europe: NATURA 2000 Sites in German Offshore Waters. Springer, 97-110.

KOCIUBA W., KUBISZ W., ZAGÓRSKI P. 2013: Use of terrestrial laser scanning (TLS) for monitoring and modelling of geomorphic processes and phenomena at a small and medium spatial scale in Polar environment (Scott River - Spitsbergen). Geomorphology (on-line access). Available online 16 February 2013.

LI J., HEAP A.D. 2008: A Review of Spatial Interpolation Methods for Environmental Scientists, Geoscience Australia, Record 2008/23, Canberra.

MALEJKA W., PALCZYŃSKI M, FREJLICHOWSKI D. 2012: Interpolation methods and the accuracy of bathymetric seabed models based on multibeam echosounder data. Intelligent information and database system, part III, lecture notes in artificial intelligence 7198, 466-475.

MERWADE V. 2009: Effect of spatial trends on interpolation of river bathymetry. J. Hydrol. 371, 169-181.

OSTROWSKI P. 2006: Wykorzystanie GIS i GPS w badaniach hydrograficznych prowadzonych dla celów dokumentowania warunków geologiczno-inżynierskich (na przykładzie dużej rzeki nizinnej i sztucznego zbiornika) [GIS and GPS application for hydrographic research carried out for engineering-geological documentation purposes (in example of large lowland river channel and artificial pond)]. Zeszyty Naukowe Politechniki Białostockiej, Budownictwo 28 (I): 239-247 (Engl. summ.).

RÓŻYCKI S.Z., SUJKOWSKI Z. 1936: Profile geologiczne przez Warszawę [Geological cross-sections of Warsaw]. Zarząd Miejski w Warszawie, Warszawa.

SARNACKA Z. 1992: Stratygrafia osadów czwartorzędowych Warszawy i okolic [Stratigraphy of quaternary sediments of Warsaw and its vicinity]. Prace PIG 138, 36 (Engl. summ.).

SCHUMM S.A., THORNE C.R. 1989: Geologic and geomorphic controls on bank erosion. In: M.A. Ports (Ed.). Hydraulic Engineering. New 
York, Proceedings of the American Society of Civil Engineering, 106-111.

SKIBIŃSKI J. 1963: Wleczenie rumowiska dennego przez Wisłę w rejonie Warszawy [Bottom bed-load transport by Vistula in Warsaw region]. Wiadomości Stużby Hydrologicznej i Meteorologicznej 53, 3-37 (Engl. summ.).

STARKEL L. 1983: The reflection of hydrologic changes in fluvial environment of the temperate zone during the last 15000 years. In: J. Gregory (Ed.). Background to Paleohydrology. J. Wiley, Chichester, 213-234.

STARKEL L. 2001: Historia doliny Wisły od ostatniego zlodowacenia do dziś [History of the Vistula River valley since the last ice age to modern times]. Monografie IGiPZ PAN 1, 263.

ŠILJEG A., LOZIĆ S., ŠILJEG S. 2015: A comparison of interpolation methods on the basis of data obtained from a bathymetric survey of Lake Vrana, Croatia. Hydrology and Earth System Sciences 19, 3653-3666.

TAN Q., XU X. 2014: Comparative Analysis of Spatial Interpolation Methods. An Experimental Study, Sensors \& Transducers, 165, 155-163.

THORNE C.R., HEY R.D., NEWSON M.D. 1997: Applied Fluvial Geomorphology in River Engineering Management. J. Wiley and Sons, Chichester.

VANDERBERGHE J. 2002: The relation between climate and river processes, landforms and deposits during the Quaternary. Quaternary International 91, 17-23.

ZIELIŃSKA M. 1960: Zmiana niwelety Wisły w Warszawie na tle zmian profilu podłużnego środkowej Wisły [Changing the grade line of the Vistula river in Warsaw in the background of changes the longitudinal profile of the middle Vistula]. Gospodarka Wodna 11, 477-480 (Engl. summ.).

ZWOLIŃSKI Z. 2010: Geografic information system - water in the environment. Bogucki Wydawnictwo Naukowe, Poznań.

ŻELAZIŃSKI J., BRAŃSKI J., KADŁUBOWSKI A., WERESKI S. 2005: Application of the CCHE Models for Explanation of Factors Causing Deep Erosion of Vistula River Bed in Warsaw. Publs. Inst. Geophys. Pol. Acad. Sc. E-5 (387), 87-113.
Streszczenie: Budowa i możliwości wykorzystania cyfrowego modelu strefy korytowej rzeki na przykładzie fragmentu warszawskiej Wisły. Duża dynamika środowisk fluwialnych na obszarze Niżu Polskiego narzuca konieczność posługiwania się w trakcie analizy procesów korytowych modelami przestrzennymi koryta określanymi zawsze dla konkretnych warunków przepływu. W pracy zaproponowano procedurę konstrukcji cyfrowego modelu rzeźby strefy korytowej Wisły w środowisku GIS na podstawie wyników badań batymetrycznych prowadzonych zestawem składającym się z echosondy sprzężonej z odbiornikiem DGPS; pomiarów GNSS RTK; analizy materiałów teledetekcyjnych oraz cyfrowego modelu terenu. Przedstawiono przykłady wykorzystania tak tworzonych modeli do charakterystyki środowiska koryta warszawskiej Wisły. Koryto Wisły na badanym odcinku to forma o zróżnicowanej morfodynamice. Obejmuje strefę quasi-naturalną, charakteryzująca się względną swobodą procesów erozji i depozycji oraz strefę koryta uregulowanego. Poza zabudową hydrotechniczną czynnikiem warunkującym charakter współczesnych procesów korytowych na odcinku uregulowanym jest jego budowa geologiczna, a głównie morfologia i litologia podłoża współczesnych aluwiów Wisły.

Stowa kluczowe: cyfrowy model strefy korytowej, GIS, morfodynamika koryta, GNSS-RTK

\section{MS. received November 2015}

\section{Authors' addresses:}

Michał Brach, Marek Przywózki

Katedra Urządzania Lasu, Geomatyki i Ekonomiki Leśnictwa

Wydział Leśny SGGW

ul. Nowoursynowska 159, 02-776 Warszawa

Poland

Tomasz Falkowski, Piotr Ostrowski

Katedra Geoinżynierii

Wydział Budownictwa i Inżynierii Środowiska SGGW

ul. Nowoursynowska 159, 02-776 Warszawa

Poland 